\title{
MÜŞTERİ DENEYIMMLERINDEN ÖĞRENME: AKILLI HATALAR GÜÇLÜ MARKALAR
}

Hayat AYAR SQENTÜRK ${ }^{1}$

\section{Öz}

Hatalar her zaman mükemmel olmayan bir mühendislik, tasarım veya satış faaliyetlerinin sonucu olarak meydana gelmez. Sinemaseverler tarafindan kült film statüsüne kavuşmuş ve büyük bir maddi başarlya erişmiş yüzlerce kötü film varken, gişede hüsrana uğrayan yüzlerce iyi film vardır. Bu anlamda markaların hedef kitlede memnuniyetsizliğe yol açan negatif eylemlerini tanımlaması, analiz etmesi ve bilinçli deneyimlerde bulunması çok önemlidir. Ancak hataların değerli ve eşsiz yeni bilgiler üreteceğine dair inancın artmasına rağmen, hatalardan öğrenme sürecini açıklamada çok fazla yol alınamadı̆̆ ve daha fazla araştırmaya ihtiyaç duyulduğu sıklıkla belirtilmektedir. Bu çalışmanın amacl; çeşitli marka hikayeleri incelenerek i) işletmelerin ölüm katılığına düşmemek için öğrenmenin kaynă̆l olarak hataları nasıl kullanabileceğine dair yol haritası sunmak, ii) hatalardan ögrenme becerisi geliştirmeye engel olan unsurları ortaya çıkarmak ve iii) bu engellerin üstesinden gelme yollarını keşfetmektir. Böylelikle hatalardan öğrenme davranışına ilişkin ampirik ve deneysel çalışmalara katkı să̆lanacă̆ umulmaktadır.

Anahtar Kelimeler: Hatalardan Öğrenme, Müşteri Deneyimleri, Marka Başarısızlıkları.

JEL Kodları: M10, M31, M37

\section{LEARNING FROM CUSTOMER EXPERIENCES: INTELLIGENT FAILURES STRONG BRANDS}

\begin{abstract}
Failures are not always the outcome of an imperfect engineering, design or sales activity. While there are hundreds of bad movies that have reached cult status by movie lovers and have achieved great financial success, there are hundreds of better movies that were a failure at box office. In this sense, it is very important for brands to identify, analyze and consciously experience their negative actions that cause dissatisfaction with the targetted market. However, despite the growing belief that failures will produce valuable and unique new knowledge, it is often stated that there is not much proceeded on this area to explain the learning process from failures and that more research is needed. The purpose of this study is, by examining various brand stories; i) presenting a road map of how businesses can use failures as a source of learning so as not to go into rigor mortis in businesses, ii) revealing elements that prevent the development of learning skills from failures, and iii) discovering ways to overcome these obstacles. Thus, it is expected that this study will contribute to empirical and experimental studies on learning from failures.
\end{abstract}

Keywords: Learning from Failures, Customer Experiences, Brand Failures.

JEL Codes: M10, M31, M37.

\footnotetext{
${ }^{1}$ Dr., Gebze Teknik Üniversitesi, h.ayar@gtu.edu.tr
}

http://orcid.org/0000-0002-8738-4603 


\section{GİRIS}

"Çocuklar birer bireydir. Sağlıklı bir psikolojik ve zihinsel gelişimleri için tıpkı yetişkinler gibi onlar da çevresindekileri anlamlandırmalı ve öğrenmelidir. Hayat ise 1şıklardan ve gölgelerden oluşur. Eğer bizler hiç gölgeler yokmuş gibi davranmaya çalışırsak samimiyetsiz ve sahte olurduk. Elbette ki çoğu şey iyidir ama kötü şeyler de vardır ve bir çocuğu bu gerçeklikten uzaklaştırarak ona iyilik yapmış olmayız. Önemli olan bir çocuğa iyiliğin (1şığın) kötülüğe (gölgelere) karşı her zaman zafer kazanacağını öğretmektir.”

Walt Disney'den bu ilham verici alıntıyla konuşmasına başlayan Tom Boyles* dikkat çekici bir bilgiyle de Hub Live dergisinin düzenlediği 2. Marka Deneyimleri Sempozyumu'ndaki konuşmasını sürdürdü: "Bir müşterinin ürün deneyimlemesinin 11.2 milyar farklı yolu vardır. Bu rakam Disney markasının tamamını değil, Disney markasının sadece bir ürünü için geçerli olabilecek yaklaşık bir rakamdır.” Büyülü deneyimler yaşatarak mutluluk yaratmak vaadiyle serüvenine başlayan The Walt Disney Company'nin bu ihtimaller havuzunda marka vaadini yerine getirmesi için geliştirdiği pek çok strateji elbette vardır. Hiç kuşkusuz bu stratejilerin temelini şirketin "misafirleri yakın alakadar olacak şekilde iyi tanımak" felsefesi oluşturmaktadır. Bu nedenle müşteri ilişkileri yönetimi olarak bilinen bir fonksiyonun The Walt Disney Company'de “müşterinin yönettiği ilişkiler” olarak değiştirilmesi şaşırtıcı gelmemektedir. The Walt Disney Company müşterinin ihtiyaçlarını bir defada ve müşterinin tercih ettiği şekilde karşılamayı vurgulayarak müşteri ilişkisini ilerletmektedir. Disney’in büyülü dünyasındaki bu gerçeklik bütün müşteri deneyimlerini en çok arzu edildiği şekilde sürdürülebilir hale getirmek için gerçekleştirilen müşterilerden sürekli öğrenmenin sonucudur. Gerçekten de eğer sadece deneyimlerdeki iyi anlara (1şılara) odaklanıp kötü deneyimleri (gölgeleri) görmezden gelselerdi 1955 yılında California'daki açılışta yapılan hataların yarattığı müşteri memnuniyetsizlikleri ya da 1989 yılında Paris’teki açılışta insanların çalışanlara yumurta firlatacak kadar olumsuz algıları bugün 35 milyar dolarlık marka değerine sahip devasa bir eğlence-medya şirketine dönüştürülemezdi (Brand Finance, 2017). Nitekim bu başarının sırrı Tom Boyles'un kapanış sözlerinde de yerini almıştır: "Dünya üzerindeki en büyülü deneyimlerin Disney'de yaşanmasını sürdürmek istiyorsak misafirlerimizi dinlemeyi asla birakmamalıyı."

Disney Company örneğinde olduğu gibi, markalar tüm pazarlama çalışmalarını müşteri

* Disney Parks and Resorts, Müşterilerin Yönettiği İlişkiler Fonksiyonu, Başkan Yardımcısı, 2000-2005. 
merkezli (Sheth, Sisodia ve Sharma, 2000) ve pazar odaklı (Day, 1994) bir değer inşasına dönüştürmektedir. $\mathrm{Bu}$ dönüşüm müşterilerin latent ve dinamik ihtiyaçlarına cevap verebilmek üzere onlar ile sürekli işbirliği halinde olma ve onlardan öğrenme anlamına gelmektedir. $\mathrm{Bu}$ süreçte marka değeri müşteriler ile birlikte oluşturulduğu için müşteri marka için yalnızca bir ihtiyaç olmaktan çıkmakta bir firsata dönüşmektedir (Matthing, Sanden ve Edvardsson, 2004). Ancak bu gelişme işletmeler için marka değerinin ürünün fiziksel özelliklerinden daha değerli olduğu gerçeğini vurgularken, diğer yandan bu değerin tek bir gecede bile kaybedilebileceğinin habercisi olmaktadır. Bu bağlamda müşteri deneyimlerinde memnuniyetsizliğe yol açan hatalar, markalar için önemli bir öğrenme kaynağı haline gelmektedir. Ancak ilgili literatür incelendiğinde hatalardan öğrenme kavramının daha çok stratejik yönetim (Carmeli, Tishler ve Edmondson, 2012), örgütsel davranış (Carmeli, 2007), bilgi yönetimi (Storey ve Barnett, 2000) ve teknoloji yönetimi (Chiesa ve Frattini, 2011) gibi disiplinlerde konu edinildiği görülmektedir. $\mathrm{Bu}$ nedenle, müşteri deneyimlerinde memnuniyetsizliğe yol açan hatalı davranışların öğrenilmesinin değerli ve eşsiz bilgiler üreteceği inancının yaygınlaşmasına rağmen, pazarlama disiplini açısından hatalardan öğrenme sürecini açıklamada çok fazla yol alınamadığı ve daha fazla araştırmaya ihtiyaç duyulduğu dikkat çekmektedir.

Çalışmanın amacı; çeşitli marka hikayeleri incelenerek i) işletmelerin ölüm katılığına düşmemek için öğrenmenin kaynağı olarak hataları nasıl kullanabileceğine dair yol haritası sunmak, ii) hatalardan öğrenme becerisi geliştirmeye engel olan unsurları ortaya çıkarmak ve iii) bu engellerin üstesinden gelme yollarını keşfetmektir. Bu anlamda, önce markaların hata yapma gerekçeleri ve bu hataların markalar açısından önemine değinilmekte, daha sonra hatalardan öğrenme üzerine literatürdeki mevcut farklı teorik perspektifler detaylandırılmaktadır. Devamında markaların deneyimlerden öğrenme süreci ve öğrenme engelleri marka hikayeleri ile açıklanmaktadır. Çalışmanın son bölümünde ise teorik ve uygulamaya yönelik çıkarımlara yer verilmekte ve çalışma kısıtlarına değinilerek gelecek araştırmalara önerilerde bulunulmaktadır.

\section{KAVRAMSAL ÇERÇEVE}

\subsection{Markalar Neden Hata Yapar?}

Çok uzun zaman öncesinde bir işletmenin geleceğinden ürünler sorumluydu. Eğer bir işletmenin satışları düşüyorsa varılan sonuç ürünün artık başarısız olmaya başlamasıydı. Ancak günümüzde ürünlerin bu rollerini markalara bıraktığı gözlemlenmektedir. $\mathrm{Bu}$ değişimin sebepleri olarak ise yedi markalaşma günahını incelemek doğru olacaktır (Haig, 2003): 
Marka amnezi (bellek kaybı); yıllanmış markaların varoluş sebeplerini unutmasıyla ortaya çıkmaktadır. Eğer markalar öz kimliklerini unuturlarsa uzun soluklu marka bağlılıklarında sıkıntıya düşeceklerdir.

Marka egosu; markaların önem ve yeteneklerinin üzerinde kendilerine değer biçme eğiliminde olmalarıyla ortaya çıkmaktadır. Bir marka faaliyet gösterdiği pazarda tek başına yeterli olabileceğini düşündüğünde ya da marka kimliğine uygun olmayan pazarlara girmeye çalıştığında marka egosu tuzağına düşmüş olmaktadır.

Marka megalomanisi; egoizmin ileri safhasıdır. Markalar bu tuzağa düştüklerinde tüm dünya genelinde her ürün kategorisinde genişleme isteği duyarlar. Ancak markalar bunun üstesinden gelememektedir.

Marka aldanması; markaların tüm pazarlama sürecini, ürünlerinin gerçekliğini gizlemek olarak gördüklerinde ortaya çıkmaktadır. Uç vakalarda, bu eğilim marka kurgusuna ve büsbütün yalanlara götürebilmektedir.

Marka yorgunluğu; işletmelerin kendi markalarından sıkılmasıdır. Eğer yorgunluk yaratıcılığa dönüşürse satışları arttırıcı etkisi olabilmektedir.

Marka paranoyası; bir markanın şiddetli bir rekabet ile karşı karşıya kalmasıyla ortaya çıkmaktadır. Rakiplere karşı dava açma istekliliği, her altı ayda bir markayı yeniden konumlandırma faaliyetleri ve rakipleri taklit etmek için duyulan arzu marka paranoyasının temel semptomlarıdır.

Marka ilgisizliği; bir pazarın radikal yenilikler sonucunda değişime uğramasıyla ortaya çıkmaktadır. Mevcut markalar bu yeniliklere tepki veremediklerinde pazara ilgisiz ya da modası geçmiş olarak algılanma riskiyle karşı karşıya kalmaktadır.

\subsection{Hatalar Neden Önemlidir?}

Pratikte ortaya çıkan deneyimlerden öğrenme gerçekliği pazarlama araştırmalarının müşteri deneyimlerinden öğrenmek konusuna odaklanmasını sağlarken, bu çalışmaların çoğunda marka başarılarının vurgulandığı görülmektedir (Herbig ve Milewicz, 1993; Ingram ve Baum, 1997). Ancak başarılardan öğrenmenin, i) otomatikleşmeye ve güncel olaylara karş1 ilgisizleşmeye (Starbuck, 1983), ii) yapısal ve stratejik anlamda atalete (Starkey, 1998) ve iii) geleceğe dair öngörüsüzlüğe neden olacağı (Baumard ve Starbuck, 2005) göz önüne alındığında hataları üretici bir şekilde kullanma konusu araştırmacıların giderek ilgisini çekmeye başlamıştır. 
Ancak artan popülerliğine rağmen, Argyris ve Schön (1999) işletmelerin esasında tek döngülü bir öğrenme gerçekleştirdiğini yani hataların yakalandığı ve düzeltildiği ancak altında yatan nedenlerin keşfedilmediği ve onlara meydan okunmadığını ileri sürmektedir. Oysaki hatalardan ögrenme; hataların altında yatan sebeplerle ilgilenerek elde edilen bilgilerin, örgütsel bütünleşme ve örgüt içi etkin iletişim aracılığıyla örgütsel faaliyetlere yansıtılmasını içeren spesifik bir süreçtir (Madsen ve Desai, 2010). Buna göre, hatalardan öğrenme süreci çift döngülü öğrenme ile benzerlik gösterir. Çift döngülü öğrenmede hatalar tespit edilip düzeltilirken, buna sebep olan normlar, politikalar, amaçlar, stratejiler ve yaklaşımlar değiştirilmektedir (Argyris ve Shön, 1996). Gerçektende, Cannon ve Edmondson (2001), Nonaka ve Takeuchi (1995) ve Leonard-Barton (1995)'ın teorik çalışmalarının temelinde, hatalardan öğrenme becerisinin izlenilen yanlış stratejilere, mevcut rutinlere ve alışkanlıklara bağlılığı azalttığı, işletmeyi daha esnek bir yapıya kavuşturacak olan unutmayı öğrenme sürecini başlattığı; böylelikle değişime daha çabuk adapte olup örgütsel yeniliği, değişimi ve başarıyı sağladığı görülmektedir.

Öte yandan davranış teorisine göre, bir işletmenin başarıya ve başarısızlığa verdiği tepki aynı değildir (Arino ve Torre, 1998; March ve Shapira, 1992). İşletme çalışanları başarıları mevcut bilgilerin en iyi olduğunun ve geliştirilmesine gerek olmadığının bir kanıtı olarak yorumlayıp bu bilgilerin yeterliliğine gereğinden fazla güven duymakta ve marka megalomanlığı tuzağına doğru ilerlemektedir. İşletmede yeni bilgi arayışına girilmemesi örgütsel eylemsizliğe ve örgütsel bilgide durağanlığa sebep olur. Bu durum bir zaman sonra markanın pazara ilgisiz ya da modası geçmiş kalmasıyla sonuçlanır. Buna karşılık tecrübe edilen her hata işletme üyelerine modellerin yetersiz kaldığını göstermekte, daha iyi ve yeni modelleri araştırmak için motive etmektedir (Cyert ve March, 1992). Bu bakımdan hatalardan öğrenmek, problemlerin araştırılmasına izin vererek markanın yeni başarı hedefleri geliştirmesini sağlar ve bu hedeflere ulaşmayı engelleyen pazar bilgisindeki boşlukları işaret ederek nasıl giderilebileceklerine dair bir yol haritası çizer (Madsen ve Desai, 2010).

\subsection{Hatalardan Öğrenme Üzerine Farklı Teorik Perspektifler}

Hatalardan öğrenme, işletmenin pazardaki güçlere ve teknolojik gelişmelere uyum sağlayabilmek için gerçekleştirdiği deneyimsel öğrenmenin etkili ve yararlı bir yöntemidir. "Hataları üretici bir şekilde kullanmak" (Heinze, 2005) olarak da ifade edilen hatalardan öğrenmenin amacı beklenmeyen ve istenmeyen sonuçlara neden olan davranışların tekrar edilmesini engellemek ve muhtemel etkilerini pasifize etmektir (Cannon ve Edmondson, 2001). 
Harteis vd. (2008) hatalardan öğrenmeyi, bireylerin hem kendi hem de başkalarının hatalarından elde ettikleri bilgileri örgütsel faaliyetlere yansıtarak yeni bilgiler inşa etmesi olarak tanımlamıştır. Burada sözü edilen, hataların vekaleten öğrenme yolu ile de öğrenilebileceğidir. Gerçektende aynı faaliyet alanında bulunan markaların pazar, hedef kitle ve pazarlama faaliyetlerindeki paralellik karşılaşılabilecek hataları birbirine benzeştirmektedir. Üstelik rakiplerin başarı sırlarından ziyade hatalarının bilgisine erişebilirlik daha hızlı ve kolay olduğu için (Madsen ve Desai, 2010), vekaleten öğrenme markalar için etkili bir öğrenme yöntemi olabilmektedir. Örneğin, üniversite öğrencilerinin Nike'ın Vietnam'daki fabrikalarında çalışma şartlarının kötü olduğu ve işçi haklarının sömürüldüğü gerekçesiyle ürünlerini boykot etmesi Adidas ve Reebok’ı benzer boykotlarla karşı karşıya kalmamak için harekete geçirmiş ve uyguladıkları istihdam politikalarındaki hatalarından vazgeçerek eğitim olanaklarının ve asgari çalıştırma yaşının yükseltilmesi gibi uygulamalara geçiş yapmasını sağlamıştır (Ulmer, 2006).

Marka başarısını arttırmadaki önemli rolünden dolayı hatalardan öğrenme son yıllarda farklı perspektiflerde ele alınmaya başlanmıştır (Tablo 1). Örneğin, Sheppard ve Chowdhury (2005) hatalardan öğrenmeyi firmanın stratejik bir seçimi olarak ele alıp dört aşamalı (düşüş, tepki, geçiş ve sonuç) bir model sunmuştur. Bu model, bir markanın düşüşüne yol açan tüm hataların bir araya geldiğinde firmanın iflasına ya da olumlu geri dönüşüne nasıl etki ettiğini açıklamaktadır. Araştırmacılara göre hatalar; stratejiler ve pazardaki değişimler arasındaki uyumsuzluktan kaynaklanmaktadır. Markanın performansını ve dengesini bozan bu hatalara firma düzeltici tepkiler vermeye çalışır. Bu tepkiler strateji, yapı, kültür, teknoloji ve insan gibi değişkenler arasında karmaşık etkileşimleri gerektirir. Firmanın bu aşamada gösterdiği performans ve yaptığı yatırımlar eylemlerin başarılı ya da başarısızlığını belirler (Sheppard ve Chowdhury, 2005).

Mellahi (2005) hatalarda işletme yönetiminin rolünü inceleyerek dört aşamalı (kavrama, uyarı işaretleri, isyan ve çöküş) başka bir model ortaya koymuştur. Araştırmacı oluşturulan modelin her aşamasında yönetimin karşılaşabileceği sorunları incelerken, karşılaşılan zorluklara karşı yönetimin nasıl davranacağına dair önemli tavsiyelerde bulunmuştur. $\mathrm{Bu}$ tavsiyelerden ilki işletmeyi ve pazarı gerektiği gibi anlamak ve çalışanların kaygılarını da ciddiye alarak yeterli bilgi alışverişi sağlamaktır. Bu alışveriş sürecinde karşıt ve rahatsız edici görüşleri görmezlikten gelmekten ziyade onlara sahip çıkmak, görüş birliğinin muhafaza edilmesine önem vererek gruplardan yanlış kararların çıkmasına neden olan "grup düşünme" anlayışından kaçınmak gereklidir. İkincisi, uyarıcılara karşı işlerin yolunda gittiği zamanlarda 
bile duyarlı olma gerekliliğidir. Ayrıca hatalardan öğrenebilme gayretinde bulunmak da hatalarla başa çıkmanın önemli bir kriteridir (Wilkinson ve Mellahi, 2005).

Baumard ve Starbuck (2005) ise hatalardan öğrenme sürecine organizasyonel öğrenme perspektifinden yaklaşmıştır. Amaç; büyük ve küçük hataları örgütsel öğrenme ile başarıya dönüştürmektir. Buradaki kritik başarı faktörü, belirtilere yüzeysel çözüm getirmekten ziyade sebeplerine odaklanmaktır (Wilkinson ve Mellahi, 2005). Finkelstein (2003)'1n belirttiği üzere örgütlerin başarısızlıklarının sebebi operasyonel hatalar değildir. Operasyonel hatalar yanlış giden süreçlerin nedenlerini detaylı olarak açıklayabilecek ipuçlarıdır.

Son olarak hatalardan öğrenme davranışına sosyo-teknik perspektiften yaklaşan Cannon ve Edmondson (2005) hataların akıllı bir şekilde nasıl öğrenebileceğini konu edinmiştir. Bu kapsamda "hatalara farklı ve yeni bir açıdan bakma" zihniyetinin öğrenme yolculuğunun kritik ilk adımı olduğunu ileri sürerek, teknik ve sosyal sistemlerde gömülü olan öğrenme engellerini ve bunlara yönelik eylem planlarını çalışmalarında sunmuşlardır. 
Tablo 1: Hatalardan Öğrenme Konusunda Temel Araştırmalar

\section{Araştırmacılar Perspektif Araştırma} problemi

Bulgular

\begin{tabular}{|c|c|c|c|}
\hline $\begin{array}{r}\text { Sheppard ve } \\
\text { Chowdhury } \\
(2005)\end{array}$ & $\begin{array}{l}\text { Stratejik } \\
\text { seçim }\end{array}$ & $\begin{array}{l}\text { Hataların nedenleri } \\
\text { nelerdir ve } \\
\text { öğrenme süreci } \\
\text { nasıl } \\
\text { gerçekleşmektedir? }\end{array}$ & $\begin{array}{l}\text { Başarısızlık dört süreci kapsamaktadır: Düşüş, tepki, geçiş ve } \\
\text { sonuç. Eğer ilk iki aşamada uygun taktikler uygulanırsa hataları } \\
\text { durdurmak son iki aşamaya göre daha kolay olmaktadır. Bu } \\
\text { nedenle başarısızlıkların çoğunun sebebi ilk iki aşamada } \\
\text { yöneticilerin gösterdiği vurdumduymazlıktır. }\end{array}$ \\
\hline Mellahi (2005) & $\begin{array}{l}\text { Süreç ve } \\
\text { kontekst }\end{array}$ & $\begin{array}{l}\text { Uyarı sinyalleri } \\
\text { neden önemlidir? }\end{array}$ & 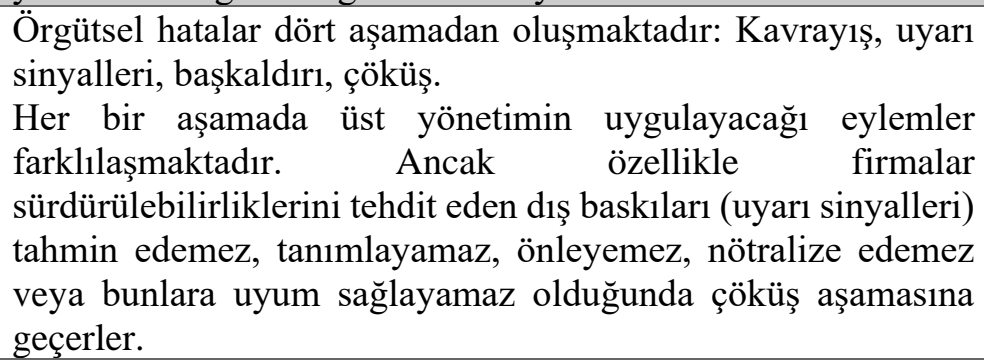 \\
\hline $\begin{array}{r}\text { Baumard ve } \\
\text { Starbuck (2005) }\end{array}$ & $\begin{array}{l}\text { Örgütsel } \\
\text { ögrrenme }\end{array}$ & $\begin{array}{l}\text { Hatalar türlerine } \\
\text { göre nası1 } \\
\text { öğrenilmektedir? }\end{array}$ & $\begin{array}{l}\text { Büyük hatalar yönetimin kontrolünün ötesindeki diş etkenlerin } \\
\text { sebep olduğu hatalar olarak görülür. Ancak büyük hatalara } \\
\text { sebep olan sürekli olarak görmezden gelinen küçük hatalardır. } \\
\text { Bu nedenle işletmeler küçük hatalardan öğrenmeyi devamlı bir } \\
\text { süreç haline getirmelidir. }\end{array}$ \\
\hline $\begin{array}{r}\text { Cannon ve } \\
\text { Edmondson } \\
\text { (2005) }\end{array}$ & $\begin{array}{l}\text { Sosyo } \\
\text { teknik }\end{array}$ & $\begin{array}{l}\text { Hatalardan akıllıca } \\
\text { ögrenmek ne } \\
\text { anlama } \\
\text { gelmektedir? }\end{array}$ & $\begin{array}{l}\text { Hatalardan öğrenmek ve her birini akıllı hatalara dönüştürmek } \\
\text { için teknik ve sosyal engellerin anlaşılması ve ögrenilmesi } \\
\text { gereklidir. Öğrenmek ise } 3 \text { önemli aktiviteyi gerektirmektedir: } \\
\text { hataları tanımlamak, analiz etmek ve deneyimlerde } \\
\text { bulunmaktır. }\end{array}$ \\
\hline Carmeli (2007) & Davranış & $\begin{array}{l}\text { Hatalardan } \\
\text { öğrenme } \\
\text { davranışının } \\
\text { öncülleri nelerdir? }\end{array}$ & $\begin{array}{l}\text { Sosyal sermayenin güçlü olduğu işletmelerde psikolojik } \\
\text { güvenlik hissi yüksektir. Psikolojik güvenliğin yüksek olduğu } \\
\text { çalışma ortamında çalışanlar hataları bir suç olarak görmemekte } \\
\text { ve onları bir öğrenme kaynağı olarak ele almaktadır. }\end{array}$ \\
\hline $\begin{array}{r}\text { Madsen ve } \\
\text { Desai (2010) }\end{array}$ & $\begin{array}{l}\text { Örgütsel } \\
\text { Öğrenme }\end{array}$ & $\begin{array}{l}\text { Başarılardan } \\
\text { ögrenmek ve } \\
\text { hatalardan } \\
\text { öğrenmek } \\
\text { birbirinden farklı } \\
\text { mıdır? }\end{array}$ & $\begin{array}{l}\text { Hatalardan elde edilen bilgiler başarılardan elde dilen bilgilere } \\
\text { göre daha yavaş değer kaybetmektedir. Bu anlamda hatalardan } \\
\text { öğrenmek başarılardan öğrenmeye göre daha etkili çıtılara } \\
\text { dönüşen bir süreçtir. }\end{array}$ \\
\hline
\end{tabular}

Yapılan farklı perspektifteki bu çalışmalar hataları, geleneksel yaklaşımın algılamalarından sıyırıp öğrenme odaklı yepyeni bir çerçeveye oturtmuştur. İki bakış açısı arasındaki farklılıklar ise Cannon ve Edmondson (2005)'un çalışması temel alınarak Tablo 2'de gösterilmektedir. 
Tablo 2: Hatalara Geleneksel ve Öğrenme Odaklı Yaklaşım

Geleneksel Yaklaşım

Hatalar kabul edilemez

Hatalardan kaçınmayı içerir

Kendini korumac1

Hatalara psikolojik ve

kişilerarası tepkiler

Yönetme yaklaşımı

Yönetimsel odak
Öğrenme Odaklı Yaklaşım

Hatalar sağlıklı bir deneyimleme ve öğrenme sürecinin doğal bir yan ürünüdür

Akıllı hatalardan öğrenmeyi ve öğrenilen derslerin örgüt içi iletişimini içerir

Kişisel ve örgütsel avantaj yaratmak için her hatayı bir firsat olarak görerek merak, inanç ve araştırma hevesi duymak

Geleceğe adapte olmak, öğrenmek ve büyümek için örgütsel kapasite ihtiyacını tanımlamak

Gelecekteki başarıya yatırım desteği

\subsection{Deneyimlerden Öğrenme Süreci: Markalar Hatalarından Nasıl Öğrenir?}

Hatalardan öğrenmek bir süreç olduğu kadar aynı zamanda bir sonuçtur. Sonuca ulaşabilmenin ilk adımı süreci oluşturan bileşenlerin tanımlanmasıdır. Bu bileşenler; hataları tanımlamak, analiz etmek ve bilinçli denemelerde bulunmaktır (Cannon ve Edmondson, 2001; Cannon ve Edmondson, 2005; Edmondson, 2011).

\subsubsection{Hataların Tanımlanması}

Hata, beklenilen ve arzu edilen sonuçlardan sapma olarak tanımlanmaktadır. $\mathrm{Bu}$ sapmaları tam zamanında ve proaktif bir şekilde teşhis etmek hatalardan öğrenme sürecinin ilk aşamasıdır (Cannon ve Edmondson, 2005). Bu yüzden araştırmalar marka başarısızlığına yol açabilecek pek çok hata türüne yer vermiştir. Örneğin Heinze (2005) hataları, prosedüral bilginin parçası olan ve olmayan hatalar olmak üzere ikiye ayırmaktadır. Eğer tespit edilen hata, prosedüral bilgisinin bir parçası ise, hata tekrarlanacak ve öğrenme, meydana gelen diğer hatalardan öğrenmelere göre çok daha zor gerçekleşecektir. Hataları büyüklüklerine göre ele alan Starbuck ve Hedberg (2001) ise orta dereceli ve kronik hatalar şeklinde iki ayrım yapmıştır. Orta dereceli hatalar markada birtakım parametrik değişimleri tetiklemektedir. Bu değişimler başarıya ulaşmada yetersiz kalıyorsa firma yeni alternatifler için çevresel araştırmalara başlayacaktır. Böylelikle başarı için bilgi yaratılacaktır. Kronik hatalar ise büyük ve yıkıcı etkidedir. Firmanın pazarının, ürünlerinin ve stratejilerinin değiştirilmesini gerektirebilmektedir.

Ancak Edmondson (1999) araştırmalarda bu tür ayrımlara yer verilmesine karşın, işletmelerde hataların yaygın olarak üç kategoride toplandığını iddia etmiştir. Bu hatalar 
önlenebilir, karmaşık ve akıllı hatalardır. Önlenebilir hatalar; yetenek, dikkat ve uygun eğitim olmadığında meydana gelen sapmalardır. Toyota Production System önlenebilir hataların tespiti için oluşturulmuştur. Karmaşık hatalar; karmaşık sistemlerin özündeki belirsizlikten kaynaklanmaktadır. Uçak şirketleri ve nükleer enerji santralleri gibi karmaşık yapılı örgütlerde sistem hataları daimi bir risk oluşturmaktadır. Akıllı hatalar ise işletmelerde olumlu olarak kabul edilen hatalardır. Çünkü bu hatalar, işletme dikkatinin potansiyel problemlere çekilmesinde, bu problemlerin çözümüne yönelik araştırmalar yapılmasında ve çalışanların motive edilip harekete geçirilmesinde yarar sağlayarak işletmenin rekabet ortamında yukarıya sıçramasına yardım edecek değerli yeni bilgileri yaratır (Sitkin, 1992; Edmondson, 2011). Sitkin (1992)'in onları akıllı başarısızlık olarak isimlendirmesinin nedeni de budur.

İşletmelerden beklenen tespit edilen hatalardan hepsinin akıllı hatalara dönüştürülmesidir. Hataların akıllı hatalara dönüştürülmesi sürecinde açıkça tanımlanması, sonuçlarının sınırlandırılması, hızlı geri bildirim sağlanması ve örgütün etki alanına odaklanılması gerekir (Sitkin, 1992). Dönüştürülme sürecinin kısa olması zamanın ve diğer kaynaklardaki yatırımın verimsizliğini önler ve maliyet etkinliği sağlar (Cannon ve Edmondson, 2001). Örneğin, bir ürün geliştirme takımı ürün geliştirme esnasında küçük ölçekli testler gerçekleştirerek veya ürün lansmanı öncesinde tüketici araştırmaları yaparak ürün başarısızlıklarından ve süreç hatalarından kaçınabilmektedir.

\section{Örnek Vaka 1: Coca-Cola “New Coke” Hatası}

Dünya genelinde günde yaklaşık bir milyar ürün satışı ile Coca Cola, bir marka başarısından söz edildiğinde tüketici zihninde canlanan ilk marka olmaktadır. Bu başarısını kuşkusuz 1880'li yıllarda ilk kez pazara sunulduğunda sektördeki ilk marka olmasına borçludur. Hatta pazardaki bu öncülük marka ismini ürün ismi haline getirerek Coca Cola'yı jenerik marka yapmıştır. Öyle ki, 1950’li yılların sonlarına gelindiğinde Coca Cola en yakın rakibi Pepsi'den 5 kattan daha fazla satış rakamına sahipti. Ancak sonraki yıllarda Pepsi atağa geçerek markasını "gençliğin markası" olarak yeniden konumlandırdı. Bu karar oldukça riskli olmasına rağmen Coca Cola'nın eskimiş ve klasik imajına karşı başarılı oldu. Artık müşteriler daha şekerli bir tada sahip olan Pepsi’yi tercih etmeye başladı. Pepsi buradan aldığı güçle saldırgan "Pepsi Meydan Okuyor" kampanyasını dünyaya sundu ve reklamlarında Don Johnson ve Michael Jackson'ın kullanıldığı “Pepsi Nesli” kavramı ile pazar payını tüm dünyada arttırdı (Özer, 2009).

Satışların düşmesi ve tüketicilerin Pepsi'nin tadını tercih etmesi, ürün yöneticilerini yeni bir formül arayışına itti ve sonucunda yeni formüllü New Coke üretildi. Bu ürün için yapılan 
piyasa araştırmaları sırasında firmanın en çok önem verdiği ve üzerinde yoğunlaştı̆̆ 1 bölüm 200 bin tüketici ile gözü kapalı yapılan lezzet testleriydi (Turgut, 2005). Bu lezzet testlerinde New Coke, yeni tat ve tasarımıyla hem klasik Coca Cola'ya hem de rakibi Pepsi'ye göre olumlu notlar aldı. Test sonuçlarına fazlasıyla inanan Coca Cola yönetimi, aynı anda, aynı ürün kategorisinde iki farklı ürün üretemeyeceğini düşünerek klasik Coca Cola’nın üretimine son verip sadece yeni formüllü New Coke üretmeye karar verdi ve 23 Nisan 1985'de lansmanı gerçekleştirdi. Bu kararın açıklanmasından sonra Amerikan halkı New Coke'u boykot çalışmaları başlattı. Firma bir anda 0800'lü müşteri hizmet hattına bırakılan 6.000 arama ve iletilen 40.000'in üzerinde şikayet mektubu ile karşılaştı (Özer, 2009). Tüketiciler, 100 yılı aşkın tarihi içerisinde bir "Amerikan Efsanesi” olarak kabul edilen klasik formüllü Coca Cola'nın böyle bir anda gözden çıkarılmasını kabullenmediler (Haig, 2003).

Coca Cola yönetimi New Coke hatasını kabullendi ve 10 milyon dolar harcadıkları piyasa araştırmalarında hataya neden olan gerekçeleri ortaya çıkarmaya odaklandı. Şirketin pazarlama uzmanları yapılan piyasa araştırmasının yeni formülün başarısına odaklandığını oysaki eski tada bağl1lığın ne kadar güçlü olduğu konusunda gerçekleştirilmesi gerektiğini fark ettiler. Dolayısıyla hatayı doğuran ilk sebebin, marka ile tüketici arasında ürünün kalitesinden bağımsız olarak kurulan bağı ve marka algısını göz önüne almamaları olduğunu gördüler. İkinci olarak, rakiplerinin ürününün tadına benzer formül üretip onları klonlamanın hata olduğunu anladılar. Sonra, başarılı bir marka olarak kendilerinin ticari bir markadan daha çok "aşk markası" olduklarını hesaba katmadıklarını fark ettiler. Bunun sonucunda 87 gün sonra dönemin Coca Cola Başkanı Roberto Goizueta, basının önüne çıktı ve "Mesajınızı aldık" açıklamasını yaptı. Artık New Coke üretimi durdurulup, yeniden eski formüle dönme kararı alınmıştı (Özer, 2009).
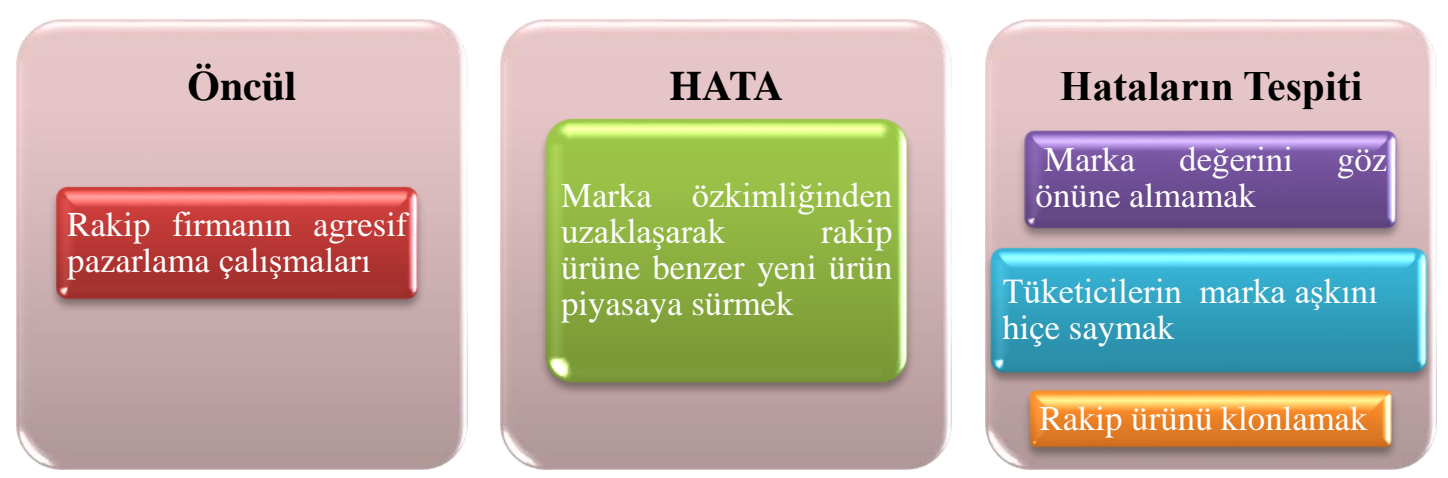

Şekil 1: New Coke Hata Nedenleri 


\subsubsection{Hataların Analizi}

Hataların analizi; hataların temel nedenlerinin daha iyi anlaşılması için onları tespit etmenin ötesinde gerekli bir eylemdir. Bu eylem, doğru çözümler üreten ve doğru dersleri öğreten karmaşık metotların kullanılması için disiplin ve heyecan gerektirir (Edmondson, 2011). Doğru bir analiz işletmedeki diğer üyelerin yapılan hatadan öğrenmesini sağlamakta, onlara yeni perspektif ve görüşler kazandırmaktadır (Cannon ve Edmondson, 2005). Buna göre; hataların uzman kişiler tarafından tartışılabileceği ve bilimsel metotlar ile irdelenebileceği örgüt içi formal grup ve süreçlerin oluşturulması gerekmektedir. $\mathrm{Bu}$ grupların yeterli teknik ekipmanlara, analizde uzmanlığa ve farklı görüş perspektiflerine sahip olması analizlerin güvenilirliğini arttıracaktır (Cannon ve Edmondson, 2001). Bununla birlikte, çalışmalarda yapılan analizlerin güvenilirliğini etkileyen iki unsura dikkat çekilmiştir. İlki; başarısızlı̆̆ derinlemesine incelemenin duygusal anlamda tatsız ve kendi kendine olan saygıyı yitirme hissi yaratmasıdır. Diğeri ise; marka hatalarının analizi nedensel belirsizlikten dolayı sabır, tolerans, açıklık ve sorgulama yetilerini gerekli kılmaktadır. Oysaki yöneticiler genellikle katiyeti, etkililiği ve düşüncenin yansımadığı hızlı eylemleri ödüllendirmektedir (Edmondson, 2011). Söz konusu sebeplerin ilki Canon ve Edmonson'un (2005) çalışmasına göre sosyal engellerden, ikincisi teknik bilgi ve beceri eksikliğinin neden olduğu teknik engellerden ileri gelmektedir.

\section{Örnek Vaka 2: Harley Davidson'in Marka Genişletme Kararı}

Harley Davidson'ın müşterileri markaya olan sadakatlerinin yanı sıra markaya aşk ile bağlıdır. Motosikletlerinin teknik açıdan çok ileride olup olmaması ya da yakıt deposunda bir sızıntı olup olmaması onların merkezinde olan bir konu değildir. Harley Davidson kullanıcılarının odaklandığı nokta motosikletlerinin onlara verdiği özgürlük ve güç duygusudur. Marka sahip olduğu bu imajı marka genişletme faaliyetlerinde kullanmak istedi ve markanın ismini taşıyan tişört, çorap, çakmak ve aksesuar gibi ürün kategorilerine taşımaya karar verdi. Markanın tutkunları firmanın bu kararından rahatsızlık duysa da asıl problem firmanın tıraş losyonu ve parfüm kategorisinde marka genişlemeye karar vermesiyle çıktı. Maskulen bir imaja sahip olan motosiklet markasının kullanıcıları için bu ürün kategorileri markadan uzaklaşma sebebiydi. Piyasada pek çok marka genişlemesi örneği varken kendilerinin bu konuda müşterilerinden çok fazla tepki görmesi firmanın pazar araştırmacılarının ve yöneticilerinin dikkatini çekti. Bu süreçte yapılan tüketici anketleri, müş̧teri değerlemeleri ve pazarlama elemanlarının analizleri sonucunda markanın sahip olduğu maskulen, sert ve güçlü değerlerin marka genişlemesinin yapıldığı ürün kategorilerinde hayat bulamayacak değerler olduğu tespit edildi (Y1lmaz, 2013). Elde edilen bilgilerle tutarlı 
olarak, ürün ve pazarlama yöneticileri gelecekteki yeni girişimlerde dikkate alınması için hayati nitelikte dersler çıkardı. Bunlar; i) marka değerlerine odaklanma, ii) çekirdek müşteriyi markaya yabancılaştırmama, iii) bazen daha çok şeyin daha az şey anlamına geldiğini bilme, iv) temel yeteneklere sımsıkı tutunma ve v) özenle müşterilerin marka aşkını elde tutmaktır.
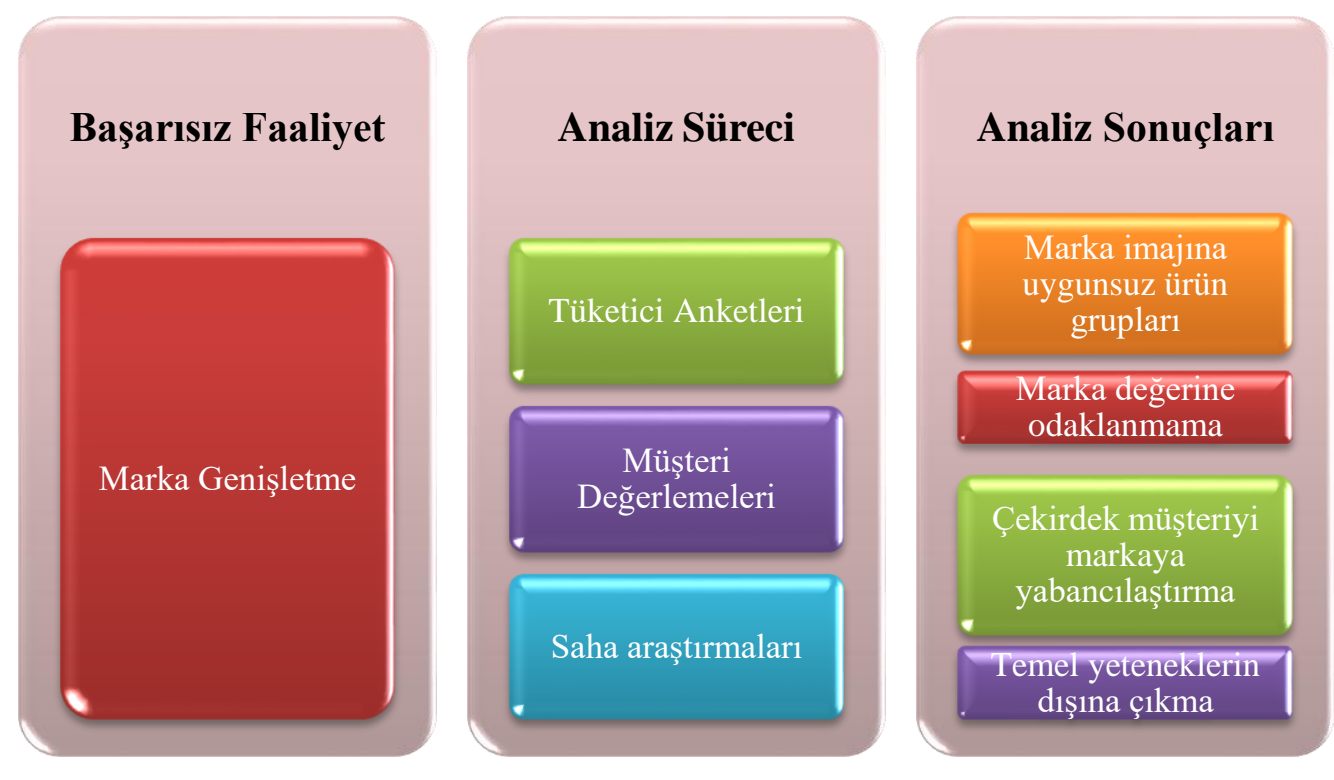

Şekil 2: Marka genişletmede hataların analizi

\subsubsection{Bilinçli Deneyimler Gerçekleştirme}

Deneyimler hataların doğru tespit edilip nedensel kökleri doğru analiz edildikçe bilinçlenmektedir. Bilinçli yapılan deneyimler karşılaşılacak hata sıklığını düşürürken; ürün, hizmet ve yenilik için yeni fikirler, problemler için ise farklı çözümler üretme olasılığını arttırır (Cannon ve Edmondson, 2005). Ancak bazı araştırmalar ne kadar doğru yer ve zaman tespit edilse de hataların insan hayatının kaçınılmaz bir parçası olduğunu ve yapılan her bir girişimde mutlaka hata ve risk payı olduğu gerçeğini göstermektedir (Edmondson, 2011). Nitekim belirtmek gerekir ki mümkün olabilecek her başarısızlık ve hatayı önleme telaşına düşüldüğü takdir de gelişme ve öğrenme fırsatları sınırlandırılmış olunacaktır (Lehman, 2009). Burada önemli olan dengeli ve tarafsız kanıtlar aramak yerine kendi görüşlerine, anlayışlarına ve inanışlarına uyan bir görüşü destekleme eğilimi olarak bilinen doğrulama yanlılı̆̆ı'na düşmemektir. $\mathrm{Bu}$ yüzden bilinçli deneyimler insanların sadece kendi görüşlerini doğru varsaymasını değil kendi görüşlerini gerektiğinde yanlışlayacak girişimlerin tasarlanmasını ve test edilmesini gerektirir (Cannon ve Edmondson, 2005). Önemli olan hataları verimli kullanabilecek bir örgüt yapısının ve ruhunun oluşturulmasıdır. Bu sayede en çok hatayı yapan kazanmaktadır (Farson ve Keyes, 2003). 


\section{Örnek Vaka 3: Denemelerle Başarıyı Yakalama Örneği: Cyristal Pepsi’den Aquafina'ya}

Pepsi 1980'lerin sonlarında, kahvaltıda kola içen tüketiciler grubunu keşfederek eski formül kadar şekerli, fakat klasik Pepsi'den iki kat daha fazla kafein içeren yeni bir ürün hazırladı: "Pepsi AM". Ancak böyle bir ürüne, bir alt marka yaratacak kadar büyük bir talep olmadığı için ürün başarılı olamadı. Pazarlamacılar başarılı olamama sebeplerini analiz etmesi sonucunda önemli sonuçlara ulaştı. İlki tüketicilerin böyle bir ihtiyaçlarının olduğunun farkında olmamalarıydı. Nitekim henüz farkında olunmayan bir ihtiyacı tatmin etmek çok masraflı bir yöntemdi. Bu yüzden işletme her boşluğu doldurması gerektiğini düşünmemeliydi. İkinci sonuç ise ürünün markasında sabah saatlerini çağrıştıran AM harflerine yer verilmesiydi. Çünkü marka tüketiciye ürünün kullanılacağı zamanı dikte etmekteydi ve ürünün kullanım alanı gereksiz yere sınırlandırılmaktaydı (Özer, 2009). Hatalarını analiz ederek bu sonuçlara ulaşan Pepsi'nin pazar araştırmacıları ve yöneticileri bu doğrultuda henüz fark edilmemiş bir ihtiyaçtansa başarılı olmuş bir ürün grubunun uzantısı olabilecek yeni bir ürünü piyasaya sunma deneyimini gerçekleştirdiler: Şeffaf kola üretmek (Haig, 2003). Araştırmacılar bir yıldan fazla süren çalışmalardan sonra, şeffaf Pepsi’yi üretmeyi başardılar ve ürüne "Crystal Pepsi” ismini verdiler. Fakat ürüne Pepsi meraklıları bile ilgi göstermeyince ürün piyasadan çekildi ve yeni bir formül ile yeni bir içecek üretildi (Crystal), ancak bu ürün de tutmadı. Buradaki hatalarını da analiz eden pazar araştırmacıları başarısız bir ürünün piyasaya yeniden sunulmaması gerektiği sonucunu çıkardılar. Tekrar hataların analizine başlayan pazar araştırmacıları yaptıkları tüketici anketleriyle tüketicinin şeffaflık konusundaki beklentilerini şişe suyu üretimine girilmesiyle karşılayabileceklerini anladılar. Böylelikle her deneyimiyle daha çok bilinçlenen Pepsi Co, “Aquafina” markalı suyu pazara sundu. Bu ürün Amerika’ da başarılı oldu ve Crystal' den daha yüksek satış rakamlarına ulaştı (Özer, 2009).

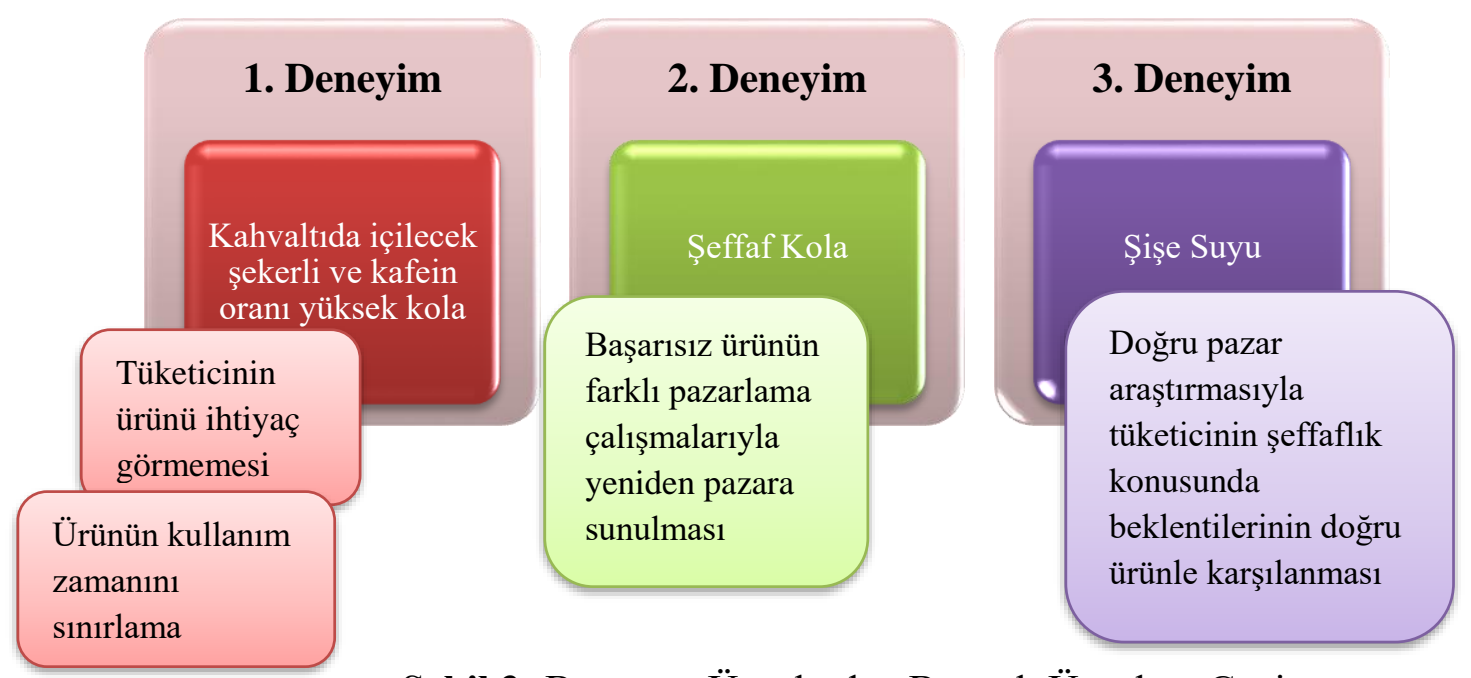

Şekil 3: Başarısız Ürünlerden Başarılı Ürünlere Geçiş 


\subsection{Hatalardan Öğrenme Engelleri: Hatalardan Niçin Korkulur?}

Gerçekleştirilen araştırmalar yöneticilerin mevcut stratejilere ve süreçlere bağlı kalması, rekabet piyasasının güçlü ve zayıf yönlerinin fark edilememesi, müşteri talepleri ve rakiplerle ilgili kör algıya sahip olunması ve hiyerarşik düzenin işletmelerde hakim olmasının hataları öğrenme sürecini olumsuz etkilediğini not etmiştir (Mellahi vd., 2002). Literatürdeki çalışmaların bulguları değerlendirildiğinde müşterilerde olumsuz marka deneyimlerine yol açan hataların öğrenilmesinde işletmelerin en çok karşılaştığı engeller üç başlık altında incelenmektedir.

\subsubsection{Sosyal (Duygusal, Psikolojik) Engeller}

Sosyal engeller yapılan hatalara verilen güçlü psikolojik reaksiyonlar ile başlar. Bazı markalar başarının verdiği krediyi kullanmayı tercih ederken, diğerleri hataların sağlayacağı firsatlardan yararlanmayı seçmektedir (Baumard ve Starbuck, 2005). Psikoloji araştırmacıları birey seviyesinde bu durumu "pozitif yanılsama" kavramı ile açıklamaktadır. Pozitif yanılsama, kişilerin kendilerini enerjik ve mutlu hissetmelerini teşvik eder, ancak; hatalarını dürüstçe kabul etmelerini önleyerek öğrenmeyi engellemektedir (Cannon ve Edmondson, 2005). Markalar da zaman zaman bu tuzağa düşerek büyük bir marka egosuna sahip olur. Marka egosu hataları gizleme, inkar ve göz ardı etme gibi davranışların gösterilmesini tetikleyerek pazarda değer kaybedilmesine yol açar (Lijander vd., 2009).

\section{Örnek Vaka 4: Kodak’ın Pazar Gelişimini Öngörememesi}

“Siz düğmesine basın gerisini biz hallederiz" sloganı ile 1888 yılında ilk makaralı filmi ve bu filmle kullanılacak kamerayı icat ederek piyasaya giren Kodak firması yaklaşık 132 yıl sonra 19 Ocak 2012'de iflas başvurusunda bulundu. Oysaki Kodak sadece fotoğrafçıllıkta değil pazarlama iletişiminde de öncü bir markaydı. Hatta kurum adını logoya dönüştüren ilk firmalardan biri olarak kabul edilmektedir. Fakat sonra dijital fotoğraf pazarının gelişimine adapte olamamış, Nikon, Panasonic ve Samsung gibi markaların gerisinde kalmıştır. Çünkü yöneticiler başarının iki ucu keskin bir bıçak olduğunu göz ardı ederek mevcut başarılardan faydalanma arzusunun peşine düşmüştür. $\mathrm{Bu}$ pozitif yanılsama pazarın dinamikliğinin görülmemesine, markaların bir ömre sahip olduğunun farkına varılmamasına ve yanlış yatırımlarda bulunulmasına neden olarak kurumsal dönüşümü engellemiştir. 

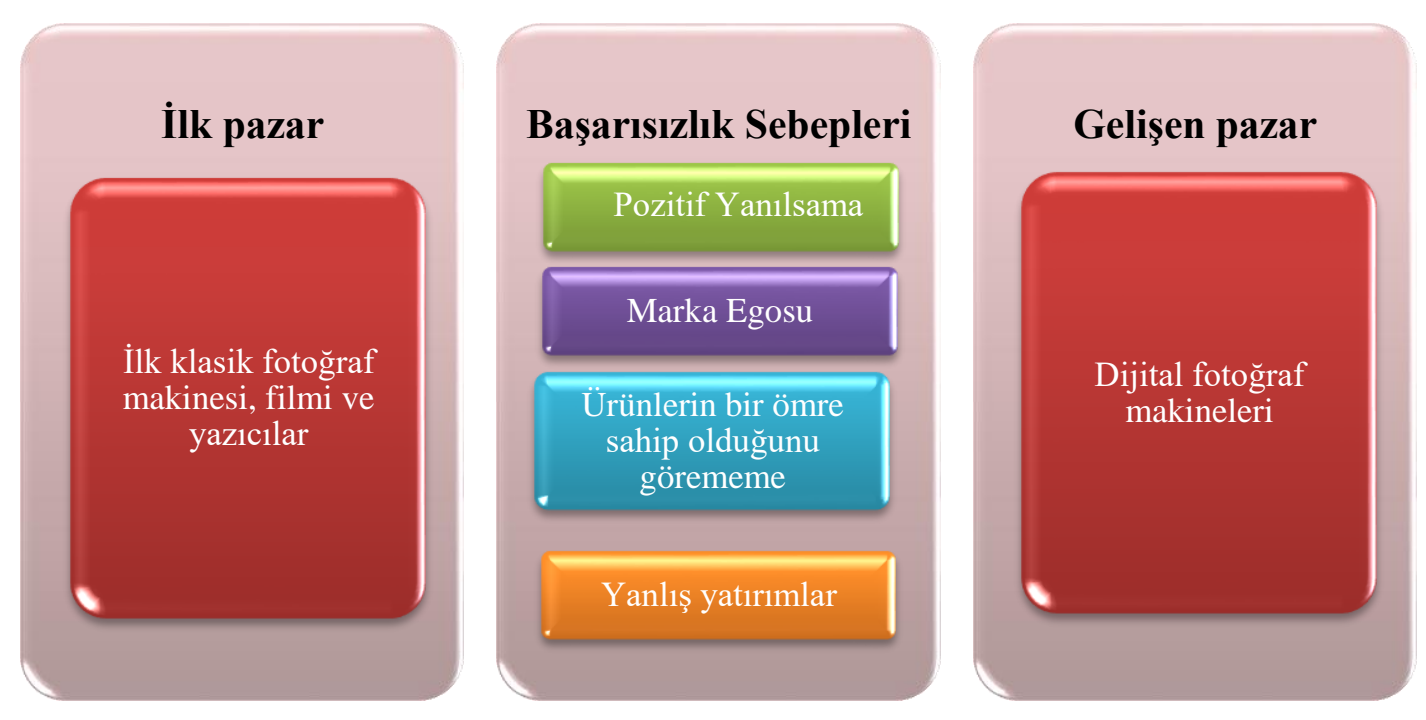

Şekil 4: Hatalardan Öğrenmede Sosyal Engeller

\subsection{2.Örgütsel Engeller}

Markaların hatalardan öğrenebilme yeteneği, onların olağanüstü durumlardan ziyade beklenen sonuçlardan sapmaya neden olan küçük veya büyük hatalarla ne kadar uğraştığı ile ölçülmektedir. Bu hataların doğru bir şekilde tespit edilememesinin sebebi, büyük hataların önemli olarak görülmeyen küçük hatalardan vuku bulmasıdır. Küçük hatalar "erken uyarı işareti”dir. Eğer dikkate alınırsa gelecekteki yıkıcı başarısızlıklardan kaçınılabilir. Ancak küçük hatalar önemsiz ve manipüle edilebilir anormallikler olarak görüldüğünden markalar bu önemli öğrenme firsatından yararlanamamaktadır. Bununla birlikte özellikle büyük hataların organizasyon içinde gömülerek göz ardı edilmesi, hafife alınması ve çok basite indirgenerek basit çözümler aranması markaları yok olmaya götüren diğer nedenlerdir (Cannon ve Edmondson, 2005).

Hatalar yolu ile öğrenebilmek için etkili bir strateji kurmak, başkalarını suçlama eğiliminden kaçınmaya ve başarısızlık sebeplerini anlamaya çalışmak bir markanın sahip olduğu kültürün parçalarıdır (Edmondson, 2011). Bu kültürü oluşturamamış yapı ve anlayışın getirdiği örgütsel engellerden kurtulmak için işletmenin sahip olduğu sosyal sermayesini etkili kullanması gerekmektedir. Çünkü sosyal sermaye, başarısızlığın başarıya dönüştürülmesinde önemli bir gelişme sağlayan, işletmede psikolojik güven inşa eden çok önemli bir faktördür (Carmeli, 2007). Bu noktada kurum içerisinde hatalardan dolayı kişilerin küçük düşürüleceği inancının yok edilmesi, başarısızlığın getireceği olumsuz sonuçların en aza indirgeneceği anlayışının geliştirilmesi ve başarısızlığın sonuçlarından motivasyon yaratılması önemlidir 
(Burleson ve Picard, 2004). Bu anlayışın yerleştiği firmaların yenilikçiliği daha yüksek seviyelere yükselmektedir (Edmondson, 1999).

\section{Örnek Vaka 5: Planet Hollywood: Bir Yönetim Başarısızlı̆̆ı}

Planet Hollywood; Slyvester Stallone, Bruce Willis, Arnold Schwarzenegger, Whoopi Goldberg ve Demi Moore ortaklığıyla ilk şubesi 1991 yılında açılan bir restaurant zinciridir. Çok kısa bir süre zarfında celebrity olarak ifade edilen insanların uğrak yeri haline gelen bu mekan bir ikon haline gelerek çok kısa bir sürede yayıldı ve dünya çapında yaklaşık 80 zincire ulaştı. Ancak kurulmasının üzerinden 10 yıl geçmeden 1999 yılında iflasını verdi ve birçok şubesi kapatıldı. Sonunda Suudi yatırımcılara devredildi. 10 yıllık süre içinde zirveden en dibe düşmenin nedenleri incelendiğinde işletmenin yönetimsel açıdan zayıflığı dikkat çekmektedir. İlk hata ana şubenin kâr durumu görülmeden dünya geneline oldukça hızlı yayılmasıydı. Kaldı ki asıl planlanan durum 2003 yılında 300 şube açmaktı. Bir başka faktör yemeklerdi. Uzun vadede başarılı olmak için menünün bir tarzının olması gerekliydi. Fakat işletme işin bu tarafını görmezlikten gelerek hiç reklam yapmamıştı. En önemli neden ise bu restaurant sadece şöhret ile özdeşleştiği için müşteriler oraya diğer ortamlarda göremeyecekleri kişileri görme umuduyla gelmeye başlamıştı. Ama bu uzun vadede bir işletmenin hayatını sürdürebilmesi için temel alabileceği birşey değildi. Hatta bu mekanı uzmanlar, turistler için ya da ailelerin çocuklarını yemeğe bir kerelik çıkarabileceği bir mekan olarak değerlendirmişti.
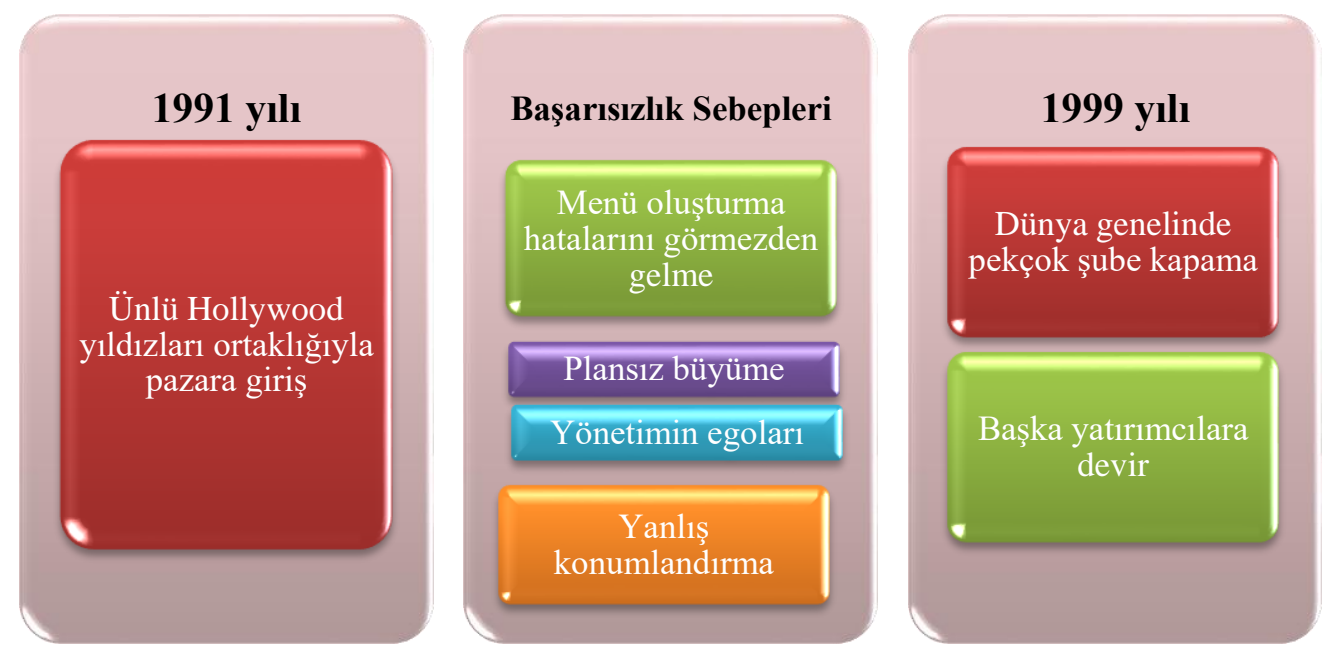

Şekil 5: Hatalardan Öğrenmede Örgütsel Nedenler

\subsubsection{Teknik Engeller}

Öğrenme üzerine yapılan araştırmalar insan sezgilerinde ve anlamlandırmadaki kısıtların insanları, hem bireysel hem de kolektif öğrenmeyi engelleyen yanlış sonuçlara 
yönlendirdiğini savunmaktadır. Buna göre hatalardan öğrenmedeki teknik engeller insanların know-how eksikliğini, karmaşık teknolojik sistemlerin anlaşılamamasını, neden-sonuç analizlerinin başarısızlığını içerir. Özellikle pazarlama fonksiyonundaki çalışanlara problem teşhisi, deney tasarımı, nitel verinin sistematik analizi, istatistiki süreç kontrolü ve analizi gibi bilimsel metotların anlaşılmasına yönelik eğitimler sağlanılarak bu engellerin üstesinden gelinmelidir (Canon ve Edmondson, 2005).

\section{Örnek Vaka 6: Winamp’ın Güncellenememesi}

Winamp, 1990'ların sonlarında rakiplerinin yavaşlı̆̆ına ve sabitliğine karşı kişiselleştirilebilir arayüzü, çalma listesi, görsel efektler, ekolayzer fonksiyonu, şarkı listesi oluşturma gibi özellikleri ile oldukça popülerdi. Bilhassa MP3'leri kullanabilme ve CD'den müzik kopyalayabilme gibi teknik özellikleriyle de oldukça talep edilen bir yazılım olmuştu. Ancak Winamp bugün varlığını sürdürse de, en yakın rakibi Itunes veya Spotify’a göre oldukça geri planda kalmaktadır. Çünkü geliştirici takımının dağıtılmasıyla değişimlere cevap verebilecek teknik uzmanlık ve ekipmanlar da kaybedilmiştir. Bir de satın alındığı şirketin yaşadığı maddi sıkıntılar nedeniyle programa yeterli yatırımlar yapılamaması, örneğin rakiplerinin mobilde kullanım popülerliğine karşın kendisinin mobilde hızlı konumlanamaması, rakiplerin her gün yeni güncellemelerle yeni özellikler kazanmasına karşı kendisindeki ses kalitesinin gittikçe düşmesi kullanıcıları diğer alternatiflere yönlendirmiştir (Lardinois, 2013).
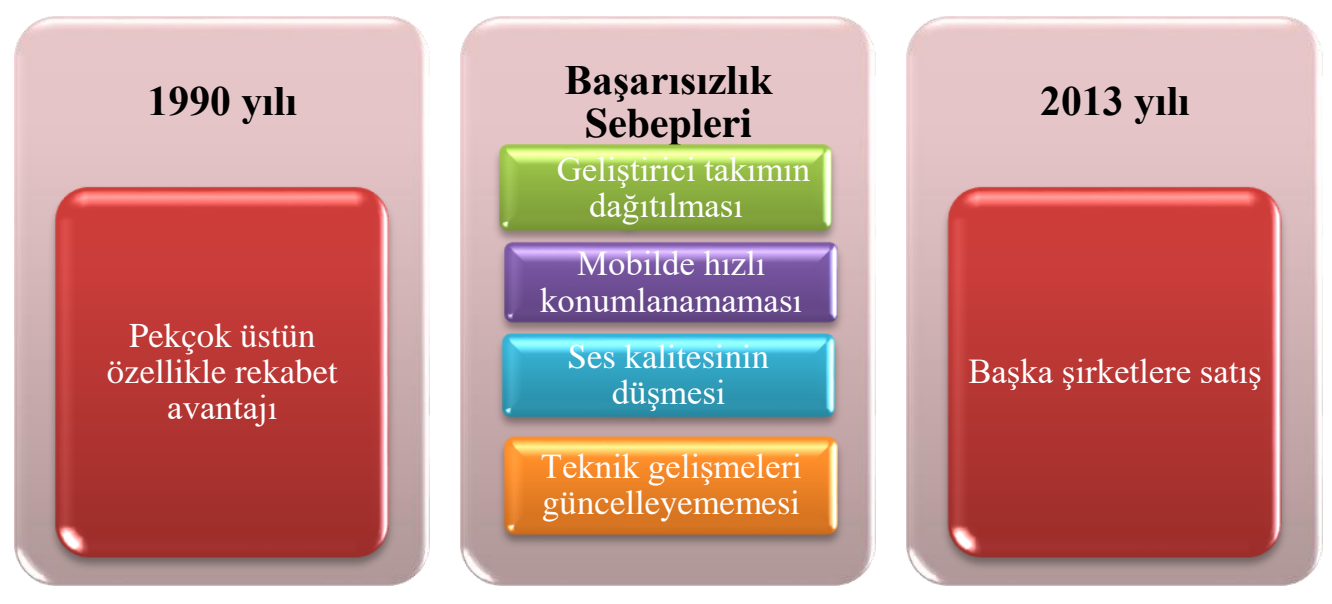

Şekil 6: Hatalardan Öğrenmede Teknik Engeller

\section{SONUÇ VE ÇIKARIMLAR}

Öngörülemez ve yüksek baskılı pazarlarda kaçınılmaz olan marka hatalarının rakiplere karşı avantaj sağlayacak değerli ve eşsiz bilgileri üreteceğinin farkına varılmasıyla müşteri deneyimlerinde yaşanılan olumsuzluklar etkili bir öğrenme kaynağı olarak ele alınmaya 
başlanmıştır (Ahluwalia vd., 2000; Ahluwalia vd., 2001). Ancak son on y1ldır literatürün ilgisini çekmesine rağmen özellikle hatalardan öğrenme kavramına bir sonuç olarak yaklaşılması öğrenme süreci, engelleri ve engellerin üstesinden gelme yolları konusunda bilgi eksikliğine yol açmaktadır. Bu bilgi eksikliği ve bilinçsizlik tüm dünyada bir zamanlar güçlü bir pazar varlığına sahip pek çok markanın ya değer kaybetmesine ya da yok olmasına neden olmuştur. Bu bağlamda çalışmada; 1) farklı teorik perspektiflerde hatalardan öğrenme kavramı açıklanmakta, 2) hatalardan öğrenme sürecinin bileşenleri tanımlanmakta ve 3) hatalardan öğrenmeye engel olan faktörler incelenmektedir. Aynı zamanda geniş bir yelpazede markaların müşterilerde memnuniyetsizliğe, negatif ağızdan ağıza iletişime ve gittikçe azalan marka bağlılığına sebep olan hataları incelenerek marka yöneticilerine ve pazarlamacılarına taktik ve stratejiler önerilmektedir.

Müşteriler rutin olarak markalar ile ilgili negatif mesajlara maruz kalabilmektedir. $\mathrm{Bu}$ nedenle tüketicilerin marka ile ilgili kötü mesajlara nasıl tepki verebileceğini belirlemek çok önemlidir. Kuşkusuz firmalar tüm tüketicilerden aynı tepkiyi almayı bekleyemez. Bazı müşteriler hataların üzerinde durmayabilirken, diğerleri markayı asla affetmeyebilir (Trump, 2014). Burada asıl önemli olan markaların müşteride memnuniyetsizlik yaratan negatif eylemlerinden nasıl öğrenebileceğini ve hataları bir öğrenme kaynağı olarak nasıl ele alabileceklerini bilmeleridir. Bu anlamda, firmalarda hataların pozitif bilgiye dönüştürülmesi zihniyetinin inşa edilmesi yalnızca marka başarılarına odaklanılmaması ile başlayacağı not edilmelidir. Sadece pozitif bilgiye odaklanma marka amnezi, egosu, megalomanlığı, ilgisizliği, aldanması, yorgunluğu ve paranoyası olmak üzere yedi marka günahının işlenmesine yol açmaktadır (Haig, 2003). Bu nedenle yöneticiler yolunda gitmeyen sonuçları dikkate almalı ve derinlemesine analiz (pazar analizi, saha araştırmaları, ürün testleri, müşteri değerlendirmeleri, tüketici anketleri...) yaparak buz dağının görünmeyen kısmını keşfetmelidir. Analizler sonucunda elde edilen her bilgi hatanın çıkmasına neden olan temel sebeplerdir. Ele alınan marka hikayelerine göre yapılan hatalar 1) marka ile tüketici arasında kurulan bağı ve marka algısını göz ardı etmek, 2) rakip ürünleri klonlamak, 3) marka kimliği ve imajına uymayan ürün gruplarına yönelmek, 4) denenmiş ve başarısız olmuş bir ürünü piyasaya yeniden sunmak, 5) fark edilmemiş bir ihtiyacı tatmin etmeye çalışmak, 6) temel yetkinliklerden uzaklaşmak, 7) yanlış konumlandırma ve pazar araştırmaları yapmak ve 9) çekirdek müşteriyi markaya yabancılaştırmaktır. Bu hatalı deneyimlere yol açan temeldeki nedenler ise 1) sosyal-psikolojik faktörler (pozitif yanılsama, ürünlerin bir ömre sahip olduğunu öngörememe, yanlış ürün ve pazar yatırım kararları), 2) örgütsel faktörler (konsept oluşturamama, plansız büyüme, üst 
yönetim egosu, hatalı marka stratejileri) ve 3) teknik faktörlerdir (kritik insan kaynağ1 planlamasında hatalar, pazar boşluklarını dolduracak altyapıya sahip olamama ve ürün/hizmet kalitesinin düşmesi). Buz dağının görünmeyen kısmının gün yüzüne çıkarılması markanın bir sonraki eylemlerini bu tuzaklara düşmeden "bilinçli denemelerde" bulunarak gerçekleştirmesini sağlamaktadır. Bilinçli bir şekilde gerçekleştirilen her deneyim markayı hatalardan uzaklaştırarak olumlu müşteri deneyimlerine yaklaştıracaktır.

Bu çalışma temel olarak; hatalardan öğrenme ve öğrenme engellerinin üstesinden gelme konusunda markalara bir yol haritası sunan kavramsal bir çalışma olmakla beraber bir takım sınırlılıklara sahiptir. İlk olarak, marka hikayelerinden çıkarılan kavramsal sonuçlardan ancak kesitsel çalışmalardan türetilebilecek nedensel çıkarımlar bulunmaktan kaçınılmalıdır. $\mathrm{Bu}$ yüzden çalışmada incelenen marka hikayelerinden elde edilen kavramsal sonuçların değişkenler (örneğin; örgütsel prosedural ve dekleratif hafıza, kollektif empati, anlamlandırma yeteneği vb.) olarak ele alınıp bir alan çalışması gerçekleştirilmesi, deneysel ve ampirik olarak test edilmesine ihtiyaç duyulmaktadır. Özellikle işletmelerin hatalardan öğrenme sürecinde çeşitli yönetim mekanizmalarının ve örgütsel uygulamaların etkisi araştırılmalıdır. Ayrıca uzun bir yaşam eğrisine sahip reel hayattaki markaların faaliyetleri gözlemlenerek vaka çalışmalarına dönüştürülmelidir. Bunun yanında öğrenme sürecini engelleyen unsurların öncülleri ve sonuçları araştırılmalıdır. Spesifik olarak fenomenolojik çalışmalar aracılığıyla çalışanlarla gerçekleştirilecek derinlemesine mülakatlar ile nitel analizler gerçekleştirilmesi farklı kavramların keşfedilmesini sağlayacaktır. 


\section{KAYNAKÇA}

Ahluwalia, R., Burnkrant, R. E. ve Unnava, H. R. (2000), "Consumer response to negative publicity: The moderating role of commitment”, Journal of Marketing Research, 37(2), 203-214.

Ahluwalia, R., Unnava, H. R. ve Burnkrant, R. E. (2001), "The moderating role of commitment on the spillover effect of marketing communications", Journal of Marketing Research, 38(4), 458-470.

Argyris, C. \& Schön, D. A. (1996). Organizational Learning II - Theory, Method, and Practice, Addison-Wesley, Reading, MA.

Argote, L. ve Epple, D. (1996), “Learning curves in manufacturing”, Science, 247, 920-924.

Arino, A. ve Torre J. (1998), "Learning from failure: Towards an evoluationary model of collaborative ventures", Organization Science, 9(3), 306-325.

Baumard, P. ve Starbuck, W. H. (2005), "Learning from failures: Why it may not happen”, Long Range Planning, 38, 281-298.

Brand Finance (2017) Global 500 The Annual Report on the World's Most Valuable Brands, http://brandfinance.com/images/upload/global_500_2017_locked_website.pdf.

Burleson, W. ve Picard, R. (2004), “Affective Agents: Sustaining Motivation to Learn Through Failure and a State of 'Stuck", Workshop on Social and Emotional Intelligence in Learning Environments. 7th International Conference on Intelligent Tutoring Systems, Maceio - Alagoas, Brazil.

Cannon, M. ve Edmondson, A. C. (2001), "Confronting failure: Antecedents and consequences of shared beliefs about failure in organizational work groups", Journal of Organizational Behavior, 22, 161-177.

Cannon D. M. \& Edmondson, A. C. (2005), "Failing to learn and learning to fail (Intelligently): How great organizations put failure to work to innovate and improve", Long Range Planning, 38, 299-319.

Carmeli, A. (2007), "Social capital, psychological safety and learning behaviours from failure in organizations", Long Range Planning, 40, 30-44.

Carmeli, A., Tishler, A. ve Edmondson, A. C. (2012), "CEO relational leadership and strategic decision quality in top management teams: The role of team trust and learning from failure”, Strategic Organization, 10(1), $31-54$.

Chiesa, V. \& Frattini, F. (2011), “Commercializing technological innovation: Learning from failures in high-tech markets", Journal of Product Innovation Management, 28(4), 437-454.

Cyert, M. R. ve March, J. G. (1992). Antecedents of the Behavioral Theory of the Firm, New York: Oxford Univrsity Press.

Day G. S. (1994), “The capabilities of market-driven firms. Journal of Marketing”, 58 (4), 37-52.

Edmondson, C. A. (1999), "Psychological safety and learning behavior in work teams", Administrative Science Quarterly, 44, 350-383.

Edmondson, C. A. (2011), "Strategies for learning from failure”, Harvard Business Review, 89(4), 48-60.

Farson, R. ve Keyes, R. (2003). Whoever Makes the Most Mistakes Wins, Free Press.

Finkelstein, S. (2003). Why Smarts Executives Fail and What You can Learn from Their Mistakes, New York: Penguin Group.

Haig, M. (2003). Brand Failures, USA: Kogan Page.

Harteis, C., Bauer, J. ve Gruber H. (2008), "The culture of learning from mistakes: How employees handle mistakes in everyday work", International Journal of Educational Research, 47, 223-231.

Haunschild, P. R. ve Sullivian, B. N. (2002), “Learning from complexity: Effects of prior accidents and incidents on airlines' learning”,Administrative Science Quarterly, 47, 609-643.

Heinze, A. (2005), "Mistake-Handling activities in the mathematics classroom”, International Group for the Psychology of Mathematics Education, 3, 105-112.

Herbig, P. ve Milewicz, J. (1993), “The relationship of reputation and credibility to brand success", Journal of consumer marketing, 10(3), 18-24. 
Ingram, P. ve Baum, J. A. (1997), “Chain affiliation and the failure of Manhattan Hotels, 1898-1980", Administrative Science Quarterly, 42, 68-102.

Lardinois, F. (2013). After 15 Years of Whipping the Llama’s Ass, Winamp Shuts Down, http://techcrunch.com/ 05.01.2014

Lehman, P. (2009). Learning from Mistakes and Failures, www.education.com/reference/article/Ref_Learning_Mistakes

Leonard-Botton, D. (1995). Wellsprings of Knowledge: Building and Sustaining the Sources of Innovation, Boston: Harvard Business School Press.

Liljander, V., Polsa, P. ve Van Riel, A. (2009), "Modelling consumer responses to an apparel store brand: Store image is a risk reducer", Journal of Retailing and Consumer Services, 16(4), 281-290.

Madsen, M. P. ve Desai, V. (2010), "Failing to learn? The effects of failure and success on organization learning in the global orbital launch vehicle industry", Academy of Management Journal, 53(3), 451-476.

March, J. G. ve Shapira, Z. (1992), "Variable risk preferences and the focus of attention”, Psychological Review, 99, 172-183.

Matthing, J., Sandén, B. ve Edvardsson, B. (2004), "New service development: Learning from and with customers", International Journal of Service Industry Management, 15(5), 479-498.

Mellahi, K. (2005), "The dynamics of boards of directors in failing organizations", Longe Range Planning, 38 , 261-279.

Mellahi, K., Jackson, P. ve Sparks, L. (2002), “An exploratory study into failure in successful organizations: The case of Marks \& Spencer", British Journal of Management, 13, 15- 29.

Nonaka, I. \& Takeuch, H. (1995). The Knowledge Creating Company: How Japanese Companies Create The Dynamics Of Innovation. New York: Oxford University Press.

Özer, N. (2009). Marka hatalar1. https://suigenuris.wordpress.com/category/marka/

Sheppard, J. P. ve Chowdhury, S. (2005), "Riding the Wrong Wave: Organizational Failure as a Failed Turnaround", Long Range Planning, 38, 239-260.

Sheth, J. N., Sisodia, R. S. ve Sharma, A. (2000), "The antecedents and consequences of customer-centric marketing", Journal of the Academy of Marketing Science, 28(1), 55-66.

Sitkin, S. B. (1992), "Learning through failure: The strategy of small losses", Research in organizational behavior, 14, 231-266.

Sturbuck, H. W. (1983), “Organizations as action generators”, American Sociological Review,48, 91-102.

Starbuck, H. W. ve Hedberg, B. (2001). How Organizations Learn from Success and Failure. In: B. Hedberg, M. Dierkes, B. Antal, C. John, L. Nonako (eds.), Handbook of Organization Learning and Knowledge, New York: Oxford University Press.

Starkey, K. (1998), “What can we learn form the learning organization?”, Human Relations, 51, 531-546.

Storey, J. ve Barnett, E. (2000), "Knowledge management initiatives: Learning from failure", Journal of Knowledge Management, 4(2), 145-156.

Turgut, Ş. B. (2005). NEW COKE: Coca-Cola'nın Pazar Araştırma Fiyaskosu. https://www.xing.com/communities/posts/new-coke-coca-colanin-pazar-arastirma-fiyaskosu1007333025

Trump, R. K. (2014), “Connected consumers' responses to negative brand actions: The roles of transgression selfrelevance and domain", Journal of Business Research, 67(9), 1824-1830.

Ulmer, R. R. (2006). Learning Through Failure. 141-152. www.uk.sagepub.com

Wilkinson, A. ve Mellahi, K. (2005), “Organizational failure: Introduction to the special issue”, Longe Range Planning, 38, 233-238.

Yılmaz, B. (2013). Markaların genişleme hatalarının analizi. http://www.pazarlamasyon.com/pazarlama/markalarin-genisleme-hatalarinin-nedenleri/ 